\title{
Pengaruh Perilaku Kecanduan Gawai terhadap Perkembangan Bahasa pada Anak Usia Dini
}

\author{
Ulufiyatul Kamilah', Jauharotur Rihlah' ${ }^{2}$, Fifi Khoirul Fitriyah ${ }^{3}$, M. Syaikhon ${ }^{4}$ \\ 1,2,3,4 Universitas Nahdlatul Ulama Surabaya \\ Surabaya, Indonesia \\ Email: 4230016006@student.unusa.ac.id ${ }^{1}$, rihlahjauhara@unusa.ac.id ${ }^{2}$, fifi@unusa.ac.id ${ }^{3}$, \\ muhammadsay87@unusa.ac.id ${ }^{4}$
}

\section{Kata kunci:}

Perilaku

Kecanduan Gawai, Perkembangan

Bahasa

\begin{abstract}
Abstrak
Gawai merupakan media komunikasi yang tidak hanya menimbulkan dampak positif, melainkan juga negatif. Tujuan penelitian ini adalah untuk mengetahui pengaruh perilaku kecanduan gawai terhadap perkembangan bahasa anak usia dini di Kecamatan Sedati Kabupaten Sidoarjo. Penelitian ini merupakan penelitian kuantitatif dengan didukung metode korelasional dengan menggunakan teknik random sampling. Teknik pengambilan data berupa kuesioner/angket yang disusun menjadi butir-butir pertanyaan dengan menggunakan skala likert. Instrumen penelitian yang digunakan telah melewati uji validitas dan reliabilitas pada TK Dharma Wanita dan dinyatakan valid dengan nilai signifikansi lebih besar dari 0.3 berada pada rentang 0.5 - 0.7 pada setiap butir pertanyaan. Selanjutnya uji reliabilitas yang diperoleh pada variabel perilaku kecanduan gawai dan perkembangan bahasa sebesar 0.776 dan 0.771 dengan kategori tinggi, sehingga butir pertanyaan pada instrumen penelitian dinyatakan valid dan reabel. Penelitian ini menggunakan teknik analisis data regresi linear sederhana, hasil yang diperoleh yakni perilaku kecanduan gawai berpengaruh negatif terhadap perkembangan bahasa pada anak usia dini dengan total pengaruh $20.7 \%$ di Kecamatan Sedati Kabupaten Sidoarjo. Penelitian ini diharapkan dapat dijadikan sebagai sumber informasi guru dan orangtua dalam mendidik anak usia dini di era digital.
\end{abstract}

\section{Keywords:}

Gadgets Addiction

Behavior,

Language

Development

\begin{abstract}
Gadgets are communication media that not only have positive but also negative impacts. The purpose of this study was to determine the effect of device addiction behavior on early childhood language development in Sedati District, Sidoarjo Regency. This research is a quantitative research supported by a correlational method using random sampling techniques. The data collection technique is in the form of a questionnaire / questionnaire which is arranged into item questions using a Likert scale. The research instrument used had passed the validity and reliability test at TK Dharma Wanita and was declared valid with a significance value greater than 0.3 in the range $0.5-0.7$ on each question item. Furthermore, the reliability test obtained on the variable of device addiction behavior and language development was 0.776 and 0.771 with the high category, so that the questions on the research instrument were declared valid and reliable. This study uses simple linear regression data analysis techniques, the results obtained are that device addiction has a negative effect on language development in early childhood with a total effect of $20.7 \%$ in Sedati District, Sidoarjo Regency. This research is expected to be used as a source of information for teachers and parents in educating early childhood in the digital era.
\end{abstract}




\section{Pendahuluan}

Golden age periode merupakan massa dimana anak berada pada puncak perkembangannya, tetapi hal ini tidak terjadi ketika anak mengalami kecanduan gawai, sehingga perkembangan anak akan mengalami keterlambatan, salah satunya perkembangan bahasa yang berkaitan dengan aspek kemampuan berbicara yang menyebabkan kemunduran tahapan perkembangan anak sesuai usianya. Kecanduan gawai berakibat pada kurangnya komunikasi interpersonal, akibatnya berdampak pada pribadi anak yang introvert, tidak sabar, dan tidak mengenal lingkungan. Hal ini terjadi akibat anak telah menemukan dunianya sendiri, yakni bersama gawai. Kecanduan gawai juga berakibat pada daya tahan tubuh dan keadaan fisik anak, sehingga mereka mengalami obesitas yang disebabkan kurangnya gerak pada aktivitas fisik dan mulai terganggu pada penglihatannya, pertumbuhan dan perkembangannya stagnan tidak ada peningkatan dan yang terpenting adalah terganggunya perkembangan sosial dan emosional dengan ditandai tidak dapat mengontrol diri (Nugraha dkk, 2019; Suhana, 2017; Gani, 2016; Uduli, 2013; Parry, 2016; Lani, 2017; Fitriyah, 2019).

Peningkatan perkembangan bahasa anak dipengaruhi oleh upaya orang tua dalam memberikan stimulasi perkembangan dengan mengajak anak berinteraksi melalui lingkungan, sehingga kosa kata anak akan mengalami peningkatan. Pendidikan yang telah dilampaui orang tua dapat berkontribusi untuk membantu meningkatkan perkembangan anak, baik pendidikan menengah dan pendidikan tinggi, melalui pengasuhan yang tepat dengan menggunakan media yang efektif, sehingga dapat mendorong perkembangan bahasa, dengan diiringi intervensi yang sesuai dengan aspek perkembangan bahasa anak. (Zauche et al, 2017; Ganapathy, 2016; Nadya \& Lynne, 2010; Tamis-LeMonda \& Rodriguez, 2009; Safwat \& Sheikhany, 2014; Ayu dkk, 2019).

Perkembangan bahasa merupakan upaya membangun kontribusi membaca sejak usia 26-61 bulan yang bertujuan untuk menghasikan perkembangan bahasa yang sesuai tahapan perkembangan, dengan membaca akan terjalin interaksi antara pembaca dan pendengar dengan baik, sehingga intervensi kemampuan berbicara dan mendengarkan telah terjalin sejak dini. (Topping et al, 2013; Zauche et al, 2017; Gikerson e al, 2015; Novrinda, 2017).

Berdasarkan hasil pengamatan yang telah dilakukan, sebagian besar orang tua anak usia dini telah memberikan fasilitas gawai, karena aktifitas orang tua yang berlebih dan minimnya pengetahuan orang tua akibat pemakaian gawai yang berlebihan pada anak. Peneliti sebelumnya menyatakan bahwa penggunaan gawai akan berdampak positif dan negatif bagi perkembangan anak, hal ini berkaitan dengan alat pendidikan yang berperan sebagai stimulasi perkembangan bahasa anak dan perubahan perilaku yang signifikan, hal ini harus diwaspadai oleh orang tua. Peran orang tua mengantisipasinya dengan cara mengawasi, memantau, dan mengendalikan anak dalam menggunakan gawai secara bijak, ibu sebagai pemegang peran utama diharapkan mampu bersikap tegas dan konsisten terkait penentuan intensitas durasi penggunaan gawai pada anak. Intensitas penggunaan gawai yang tinggi dapat berdampak pada aspek perkembangan anak, sehingga diperlukan pengetahuan yang luas terkait dampak kecanduan gawai pada anak. (Nirwana dkk, 2018; Sundus, 2018; Al-Harbi, 2015; Chusna 2017; Irmayanti, 2018; Al-Ayouby, 2017; Fajariyah, 2018).

Rumusan masalah pada penelitian ini yakni apakah perilaku kecanduan gawai berpengaruh terhadap perkembangan bahasa anak usia dini di Kecamatan Sedati Kabupaten Sidoarjo?. Penelitian ini bertujuan untuk mengetahui pengaruh perilaku kecanduan gawai terhadap perkembangan bahasa pada anak usia dini. Penelitian ini sangat penting untuk menguji perilaku

Child Education Journal. Volume 2, No. 2 December 2020, 61-67 
kecanduan gawai terhadap perkembangan bahasa dengan mengukur seberapa tinggi tingkat kategori perilaku kecanduan gawai dan perkembangan bahasa pada anak usia dini. Manfaat dalam penelitian ini yakni, a) bagi peneliti, hasil penelitian digunakan sebagai referensi peneliti selanjutnya, b) bagi pendidik, dapat menjadi wawasan pendidik dalam mengatasi permasalahan perkembangan bahasa pada anak, c) bagi sekolah, sebagai bahan referensi pemberian parenting kepada orang tua anak didik.

Menurut Sari dan Mitsalia (2016) menyatakan bahwa kategori intensitas penggunaan gawai dikatakan tinggi apabila pemakaian gawai melebihi 120 menit/hari, dalam satu kali pemakaian intensitas penggunaannya melebihi 75 menit. Orang tua yang memberikan dan memfasilitasi gawai berkali-kali (melebihi tiga kali penggunaan) dengan kapasitas waktu antara 30-75 menit akan berdampak kecanduan pada pemakainya, dikategorikan rendah jika intensitas pemakaian tidak melebihi 30 menit pada setiap pemakaian dengan kapasitas maksimal dua kali dalam penggunaanya.

Menurut Otto (2015) bahasa merupakan hal yang paling utama pada masyarakat sebagai bentuk dasar tanggapan, komunikasi, dan interaksi yang digunakan setiap hari dan setiap saat. Bahasa merupakan suatu bentuk lambang yang dapat digolongkan, dipilah, dan diklasifikasi oleh akal kita, sehingga dengan bahasa kita dapat belajar dan menjelaskan mengenai dunia. Tidak akan ada masyarakat dan kebudayaan tanpa adanya bahasa, sehingga bahasa dapat mengantarkan manusia untuk senantiasa berpikir dengan memunculkan ide-ide cemerlang yang dapat dikomunikasikan untuk kemajuan masyarakat bersama.

Penelitian yang telah dilakukan oleh Suryani (2018) yang berjudul "Pengaruh Perilaku Kecanduan Gawai Terhadap Kemampuan Bahasa Anak Usia Dini Di Kelurahan Dukuh Pakis Surabaya", menunjukkan bahwa tidak ada hubungan antara perilaku kecanduan gawai terhadap kemampuan berbahasa anak usia dini dinyatakan negatif kuat $(-0,049)$ ditandai dengan angka signifikansi sejumlah $(0,657)$.

\section{Metodologi}

Penelitian ini merupakan penelitian kuantitatif dengan didukung metode korelasional, populasi dalam penelitian ini yakni seluruh sekolah taman kanak-kanak di Kecamatan Sedati Kabupaten Sidoarjo dengan teknik random sampling, sehingga diperoleh 153 responden di 3 sekolah. Penelitian ini menggunakan instrumen penelitian dengan memakai skala likert pada setiap butir pertanyaannya, berikut tabel penggunaan skala likert sesuai tabel 1 dan tabel 2 .

Tabel 1. Skala Likert Instrumen Perilaku Kecanduan Gawai

\begin{tabular}{|l|l|}
\hline \multicolumn{1}{|c|}{ Alternatif Jawaban } & Bobot \\
\hline Sangat Tidak Setuju (STS) & Skor 1 \\
\hline Tidak Setuju (TS) & Skor 2 \\
\hline Tidak Mampu Mengatakan (TMM) & Skor 3 \\
\hline Setuju (S) & Skor 4 \\
\hline Sangat Setuju (SS) & Skor 5 \\
\hline
\end{tabular}

Tabel 2. Skala Likert Instrumen Perilaku Perkembangan Bahasa

\begin{tabular}{|l|l|}
\hline \multicolumn{1}{|c|}{ Alternatif Jawaban } & Bobot \\
\hline Tidak Pernah (TP) & Skor 1 \\
\hline Kadang-Kadang (KK) & Skor 2 \\
\hline Sering (S) & Skor 3 \\
\hline
\end{tabular}


Teknik pengumpulan data pada penelitian ini berupa kuesioner/angket yang terdiri 9 butir pertanyaan untuk perilaku kecanduan gawai dan 10 butir untuk perkembangan bahasa, dalam pengisiannya diperlukan bantuan orang tua anak yang berperan dalam memahami perilaku dan perkembangan bahasa anak. Angket yang digunakan telah melewati uji validitas dan reliabilitas yang telah diuji cobakan pada TK Dharma Wanita, sehingga hasil yang diperoleh 9 butir pertanyaan perilaku kecanduan gawai dan 10 butir perkembangan bahasa dinyatakan valid dan reliabel. Penelitian ini menggunakan teknik analisis data regresi linear sederhana, melalui beberapa tahapan yakni, memeriksa angket yang telah diisi oleh responden, selanjutnya peneliti memberikan skor jawaban yang diberikan sesuai dengan skala likert yang telah ditentukan, data yang telah diperoleh diolah yang selanjutnya akan diperoleh frekuensi, rata-rata skor dan kategori setiap variabel pada uji statistik deskriptif.

\section{Hasil dan Pembahasan}

Penelitian ini dilaksanakan di TK Khoirul Huda, TK Dharma Wanita, dan TK Ar-Rahman yang berada di Kecamatan Sedati dengan 153 responden orang tua anak usia TK B, dengan menggunakan teknik analisis regresi linear sederhana dengan bantuan SPSS versi 20.0 yang telah melewati uji statistik deskriptif yang berpacu pada nilai mean (nilai rata-rata), standar deviation (nilai simpangan baku) serta nilai maksimum dan minimum pada setiap variabel. Pengaruh perilaku kecanduan gawai merupakan variabel $\mathrm{X}_{1}$ dan perkembangan bahasa merupakan variabel Y. Berikut hasil uji statistiK deskriptif pada setiap variabel yang tersaji dalam tabel 1.

Tabel 3. Analisis Statistik Deskripstif

\begin{tabular}{|l|c|c|c|c|c|}
\hline & N & Minimum & Maximum & Mean & Std. Deviation \\
\hline Tanggung Jawab (X1) & 153 & 11 & 38 & 23.32 & 5.520 \\
\hline Pemahaman Diri (Y) & 153 & 13 & 30 & 24.38 & 3.576 \\
\hline Valid N (listwise) & 153 & & & & \\
\hline
\end{tabular}

Pada tabel 1 di atas, variabel perilaku kecanduan gawai $\left(\mathrm{X}_{1}\right)$ diperoleh jumlah data $(\mathrm{N})$ sebanyak 153 dengan nilai minimum dan maksimum berada pada angka 11 dan 38 dengan memperoleh rata-rata 23.32 dan standar deviasi (std.deviation) berada 5.520, sehingga menunjukkan nilai rata-rata melebihi standar deviasinya, artinya nilai yang diperoleh cukup baik dan sangat tinggi dengan penyebaran data yang normal dan tidak terjadi penyimpangan. Variabel perkembangan bahasa $(\mathrm{Y})$ diperoleh jumlah data $(\mathrm{N})$ sebanyak 153 dengan nilai minimum dan maksimum berada pada angka 13 dan 30 dengan memperoleh rata-rata 24.38 dan standar deviasi (std.deviation) berada 3.576, sehingga menunjukkan nilai rata-rata melebihi standar deviasinya, artinya nilai yang diperoleh cukup baik dan sangat tinggi.

Selanjutnya peneliti akan menguraikan kategori distribusi frekuensi pada responden. Berikut ini penjabaran kategori secara utuh pada table di bawah ini:

Tabel 4. Kategori Distribusi Frekuensi Perilaku Kecanduan Gawai

\begin{tabular}{|c|l|c|c|c|c|}
\hline \multicolumn{2}{|c|}{} & Frequency & Percent & Valid Percent & Comulative Percent \\
\hline \multirow{4}{*}{ Valid } & Rendah & 17 & 11.1 & 11.1 & 11.1 \\
& Sedang & 107 & 69.9 & 69.9 & 81 \\
& Tinggi & 29 & 19 & 19 & 100 \\
\cline { 2 - 6 } & Total & $\mathbf{1 5 3}$ & $\mathbf{1 0 0}$ & $\mathbf{1 0 0}$ & \\
\hline
\end{tabular}


Pada tabel 4 perilaku kecanduan gawai pada anak berada pada kategori sedang, yakni sebesar 69.9\% dengan jumlah frekuensi 107 responden.

Tabel 5. Kategori Distribusi Frekuensi Perkembangan Bahasa

\begin{tabular}{|c|l|c|c|c|c|}
\hline \multicolumn{2}{|c|}{} & Frequency & Percent & Valid Percent & Comulative Percent \\
\hline \multirow{4}{*}{ Valid } & Rendah & 22 & 14.4 & 14.4 & 14.4 \\
& Sedang & 97 & 63.4 & 63.4 & 77.8 \\
& Tinggi & 34 & 22.2 & 22.2 & 100 \\
\cline { 2 - 6 } & Total & $\mathbf{1 5 3}$ & $\mathbf{1 0 0}$ & $\mathbf{1 0 0}$ & \\
\hline
\end{tabular}

Pada tabel 5 di atas, perkembangan bahasa pada anak berada pada kategori sedang, yakni sebesar $63.4 \%$ dengan jumlah frekuensi 97 responden. Selanjutnya, sebelum dilakukan uji regresi sederhana, data terlebih dahulu diuji normalitas menggunakan kolmogorov-smirnov memperoleh besaran angka signifikansi 0.840 , hal ini dapat dinyatkan melebihi dari 0.05 , maka kesimpulan yang diperoleh bahwa data yang diperoleh berdistribusi normal. Berdasarkan hasil uji heteroskadistisitas diperoleh besarnya angka signifikansi sebesar 0.80 melebihi 0.05 atau $5 \%$, maka kesimpulan yang diperoleh tidak terjadi heteroskedastisitas pada model regresi ini. Selanjutnya data diuji menggunakan uji regresi sederhana, berikut hasilnya dapat dilihat pada tabel 5.

Tabel 6. Pengaruh Perilaku Kecanduan Gawai $\left(\mathrm{X}_{1}\right)$ terhadap Perkembangan Bahasa (Y)

\begin{tabular}{|l|l|l|l|l|l|}
\hline \multirow{2}{*}{ MODEL } & \multicolumn{2}{|c|}{ Unstandardized Coefficients } & $\begin{array}{c}\text { Standardized } \\
\text { Coefficients }\end{array}$ & \multirow{2}{*}{ t } & \multirow{2}{*}{ Sig. } \\
\cline { 2 - 6 } & \multicolumn{1}{|c|}{ B } & Std. Error & Beta & & \\
\hline \multirow{2}{*}{$\begin{array}{l}\text { 1. Constant) } \\
\text { Kecanduan (X1) }\end{array}$} & 31.260 & 1.125 & & 27.795 & .000 \\
\cline { 2 - 6 } & -.295 & .047 & -.455 & -6.286 & .000 \\
\hline
\end{tabular}

a. Dependent Variable; Perkembangan Bahasa (Y)

Berdasarkan hasil uji regresi $\mathrm{X}_{1}-\mathrm{Y}$ diperoleh nilai signifikansi (Sig.) 0.000 kurang dari nilai probabilitas 0.05 , maka dapat diambil kesimpulan $\mathrm{H}_{0}$ ditolak dan $\mathrm{H}_{1}$ diterima, mengandung arti "ada pengaruh perilaku kecanduan gawai terhadap perkembangan bahasa pada anak usia dini". Koefisien determinasi $R$ Square $\left(\mathrm{R}^{2}\right)$ sebesar 0.207 setara dengan $20.7 \%$ merupakan sumbangan pengaruh perilaku kecanduan gawai $\left(\mathrm{X}_{1}\right)$ terhadap perkembangan bahasa $(\mathrm{Y})$. Garis regresi dapat digambarkan $\mathrm{Y}=31.260-0.295 \mathrm{X}$. Nilai konstanta diperoleh 31.260 mengandung arti yang berhubungan dengan perilaku kecanduan gawai tidak terjadi $\left(\mathrm{X}_{1}\right)$ sehingga nilai konsisten perkembangan bahasa anak usia dini (Y) sebesar 31.260. Kemudian nilai koefisien regresi sebesar -0.295 yang mimiliki arti bahwa setiap penambahan $1 \%$ tingkat perilaku kecanduan gawai $\left(\mathrm{X}_{1}\right)$, maka perkembangan bahasa akan mengalami peningkatan sebesar -0.295, selanjutnya hasil nilai t hitung dalam hipotesis ini adalah -6.286 dan nilai t tabel sebesar 1.976.

Hasil penelitian ini tidak sinkron dengan hasil penelitian yang dilakukan oleh Nur Laila Mey Suryani (2018) yang menyatakan bahwa tidak ada korelasi atau pengaruh antara perilaku kecanduan gawai terhadap kemampuan bahasa anak yang menunjukkan bahwa perilaku kecanduan gawai terhadap kemampuan bahasa anak usia dini negatif kuat, $(-0,049)$ dengan nilai signifikansi sebesar $(0,657)$.

Kesimpulan yang dapat diambil pada uji regresi sederhana ini adalah perilaku kecanduan gawai berpengaruh negatif terhadap perkembangan bahasa pada anak usia dini dengan nilai pengaruh 20.7\% di Kecamatan Sedati Kabupaten Sidoarjo. Pengaruh negatif ini bermakna semakin tinggi perilaku kecanduan gawai anak usia dini, maka akan berpengaruh kecil terhadap

Child Education Journal. Volume 2, No. 2 December 2020, 61-67 
peningkatan perkembangan bahasa anak. Pada penelitian ini menunjukkan bahwa ada pengaruh perilaku kecanduan gawai dengan perkembangan bahasa anak yang berada pada taraf sedang, artinya anak yang mengalami perilaku kecanduan gawai maka perkembangan bahasa anak juga berada pada taraf yang sedang, sehingga semakin tinggi tingkat perilaku kecanduan gawai pada anak maka akan berpengaruh kecil terhadap peningkatan perkembangan bahasa anak.

\section{Kesimpulan}

Berdasarkan uraian hasil dan pembahasan di atas, maka dapat disimpulan bahwa terdapat pengaruh negatif antara perilaku kecanduan gawai terhadap perkembangan bahasa pada anak usia dini. Artinya, semakin tinggi level kecanduan gawai pada anak berdampak pada semakin rendahnya kemampuan berbahasa anak. Rekomendasi penelitian ini adalah perlu dilakukan penelitian secara mendalam melalui studi kasus pada anak usia dini untuk membahas secara detail faktor-faktor lain yang menyebabkan anak usia dini memiliki kemampuan berbahasa rendah.

\section{Daftar Pustaka}

Al-Ayouby, M. H. (2017). Dampak Penggunaan Gadget Pada Anak Usia Dini (Studi di PAUD dan TK Handayani Bandar Lampung). Skripsi. Lampung: Universitas Lampung.

Al-Harby, S. S. (2015). The Influence Of Media In Children's language Development. Journal of Education, 5(1), 1-5. DOI:10.5539/jedp.v5n1p1.

Ayu, R. F. K., Sari, S. P., Setiawan, B. Y., \& Fitriyah, F. K. (2019). Meningkatkan Kemampuan Berbahasa Daerah Melalui Cerita Rakyat Digital pada Siswa Sekolah Dasar: Sebuah Studi $\begin{array}{llll}\text { Pengembangan. Child Education Journal, } & \text { 65-72. }\end{array}$ https://doi.org/10.33086/cej.v1i2.1356

Chusna, P. A. (2017). Pengaruh Media Gadget pada Perkembangan Karakter Anak. Media Komunikasi Sosial Keagamaan, 17(2), 315-330.

Fajariyah, S. N., Suryawan, A., \& Atika. (2018). Dampak Penggunaan Gawai Terhadap Perkembangan Anak. Sari Pediatri, 20(2), 101-105

Fitriyah, F. K. (2019). Pengaruh Perilaku Agresif pada Anak Usia Dini terhadap Kecemasan dan Empati. Education and Human Development Journal, 4(1), 95-102. https://doi.org/10.33086/ehdj.v4i1.1088.

Ganaphaty, M. (2016). The Effect of Educational Media on Children's Language Development: A Case Study. Journal of English language and literature, 1-27. https://www.researchgate.net/publication/307583661_The_effects_of_educational_media_ on_children's_language_development_a_case_study.

Gani, S. A. (2016). Parenting Digital Natives: Cognitive, Emotional, and Social Developmental Challenges. International Conference on Education, 870-880. http://pasca.um.ac.id/conferences/index.php/ice/article/view/118.

Gilkerson, J., Richards, J. A., \& Topping, K. J. (2015). The Impact of Book Reading in the Early Years on Parent-Child Language Interaction. Journal of Early Childhood Literacy, 17(1), 92-110. https:/doi.org/10.1177/1468798415608907.

Irmayanti, Y. (2018). Peran Orang Tua dalam Mendampingi Penggunaan Gawai pada Anak Usia Prasekolah. Skripsi. Surakarta: Universitas Muhammadiyah Surakarta.

Lani, T. (2019). Perilaku Orang Tua terhadap Penggunaan Gawai Anak Prasekolah Serta Dampak pada Tajam Penglihatan Anak. Surabaya: Program Studi Magister Keperawatan. Universitas Airlangga.

Muduli, J. R. (2013). Addiction to Technological Gadgets and Its Impact on Health and life Style: A study on Collage Students. Master's Degree in Development Studies. India: Department Of Humanities and Social Science. National Institute of Technology India.

Child Education Journal. Volume 2, No. 2 December 2020, 61-67 
Nadya, P., \& Lynne, V. F. (2010). Father's Early Contributions to Children's Language Development in Families from low-Income Rural Communities. Early Childhood Research Quarterly, 25(4), 450-463. DOI: 10.1016/j.ecresq.2010.02.001.

Nirwana., Mappapoleonro, A. M., \& Chairunnisa. (2018). The Effect of Gadget Toward Early Childhood Speaking Ability. Indonesian Journal of Early Childhood Education Studies, $7(2), 85-90$.

Novrinda. (2017). Peran Orang Tua dalam Pendidikan Anak Usia Dini Ditinjau dari Latar Belakang Pendidikan. Jurnal Potensia. PG-PAUD FKIP UNIB, 2(1), 39-46.

Nugraha, A., Izzah, N., Hidayah, S. N., Zulfiana, E., \& Qudriani, M. (2019). The Effect of Gadget on Speech Development of Toddlers. Journal of Physics: Conf. Series, 1175, 1-7. https://iopscience.iop.org/article/10.1088/1742-6596/1175/1/012203.

Otto, B. (2015). Perkembangan Bahasa Pada Anak Usia Dini. Jakarta: Prenadamedia Group.

Parry, C. (2016). Addiction to Technological Devices: Its Effect on an Individual Health, life Style and Social Skills. Cardiff: Department of Computing \& Information System Cardif School of Management. Cardif Metropolitan University.

Safwat, R. F., \& Sheikhany, A. R. (2014). Effect of Parent Interaction language Development in Children. Department Otolaryngology, Phoniatric Unit. Faculty of Medicine. Cairo University, 30(3), 255-263. DOI: 10.4103/1012-5574138488.

Sari, P., \& Mitsalia, A.A. (2016). Pengaruh Penggunaan Gadget terhadap Personal Sosial Anak Pra Sekolah di TKIT Al Mukmin. Jurnal Profesi, 13(2), 73-77

Suhana, M. (2017). Influence of Gadget Usage on Children's Social-Emosional Development. Advances in Social-Science, Education and Humanities Research (ASSEHR), Vol 169, 224-227

Sundus, M. (2018). The Impact of Using Gadgets on Children. Journal of Depression and Anxiety, 7(1), 1-3

Suryani, N. L. M. (2018). Pengaruh Perilaku Kecanduan Gawai terhadap Kemampuan Bahasa Anak Usia Dini di Kelurahan Dukuh Pakis Surabaya. Skripsi. Surabaya: Universitas Nahdlatul Ulama Surabaya.

Tamis-LeMonda, C. S., \& Rodriguez, E. T. (2009). Parent's Role in Fostering Young Children's Learning and Language Development. Language Development and Literacy, 1-7

Topping, K., Dekhinet, R., \& Zeedyk, S. (2017). Parent-Infant Interaction and Children's language Development. Educational Phcygology, 33(4), 391-426.

Zauche, L. H., Mahoney, A. E. D., Thul, T. A., Zauche, M. S., Weldon, A. B., \& Stapel-Wax, J. L. (2018). The Power of language Nutrition for Children's Brain Development, Health, and Future Academic Achievment. Journal of Pediatric Health Care, 31(4), 493-503. https://doi.org/10.1016/j.pedhc.2017.01.007. 